Supporting Information

\title{
$\left[\mathrm{Ru}(\mathrm{bpy})_{3}\right]^{2+} @ \mathrm{Ce}-\mathrm{UiO}-66 / \mathrm{Mn}: \mathrm{Bi}_{2} \mathrm{~S}_{3}$ heterojunction and its exceptional photoelectrochemical aptasensing properties for ofloxacin detection
}

Rui Feng a , Xue Zhang a , Xiaodong Xue c, Yifei Xu ${ }^{a}$, Haolin Ding a , Tao Yan a *, Liangguo Yan ${ }^{\mathrm{a}}$, Qin Wei ${ }^{\mathrm{b}}$

${ }^{a}$ School of Water Conservancy and Environment, University of Jinan, Jinan 250022,

$$
\text { P.R. China }
$$

${ }^{b}$ Key Laboratory of Interfacial Reaction \& Sensing Analysis in Universities of

Shandong,

School of Chemistry and Chemical Engineering, University of Jinan, Jinan 250022,

China.

c Shandong Academy of Environmental Science Co., Ltd, Jinan 250013, P.R. China

* Corresponding author:

E-mail: yantujn@163.com (Tao Yan)

Fax: +86 53182765969 ;

Tel.: +86 53182765730 . 


\section{REAGENTS AND CHEMICALS.}

$\mathrm{ZrCl}_{4}, \mathrm{CeCl}_{3} \cdot 7 \mathrm{H}_{2} \mathrm{O}$, acetic acid, 4-benzenedicarboxylic acid $\left(\mathrm{H}_{2} \mathrm{BDC}\right)$, $\mathrm{Ru}(\text { bpy })_{3} \mathrm{Cl}_{2}$, chitosan $\left(\mathrm{C}_{6} \mathrm{H}_{11} \mathrm{~N}_{2} \mathrm{O}_{4}\right)$ and glutaraldehyde $\left(\mathrm{C}_{5} \mathrm{H}_{8} \mathrm{O}_{2}\right)$, ofloxacin (OFL) were purchased from Macklin Biochemical Co., Ltd (Shanghai, China). N, N-dimethylformamide (DMF) was purchased from Fuyu Fine Chemical Co., Let (Tianjin, China). $\left.\left(\mathrm{CH}_{3} \mathrm{COO}\right)_{2} \mathrm{Mn} \cdot 4 \mathrm{H}_{2} \mathrm{O}\right), \mathrm{Na}_{2} \mathrm{~S} \cdot 9 \mathrm{H}_{2} \mathrm{O}$, Ascorbic Acid (AA), alcohol, acetone, methanol were acquired from Sinopharm Chemical Reagent Co., Ltd (Shanghai, China). Mercaptoethanol ( $\mathrm{MCH}, \geq 99 \%)$ was purchased from Beijing J \& K Chemical Reagent Co., Ltd. $\mathrm{Bi}\left(\mathrm{NO}_{3}\right)_{3} \cdot 5 \mathrm{H}_{2} \mathrm{O}$ was purchased from Aladin Reagent Co., Ltd. The OFL aptamer was obtained from Sangon Biotech Co., Ltd (Shanghai, China) with the sequence as follows: 5'- $\mathrm{NH}_{2}-\left(\mathrm{CH}_{2}\right)_{6}$-ATA CCA GCT TAT TCA ATT AGT TGT GTA TTG AGG TTT GAT CTA GGC ATA GTC AAC AGA GCA CGA TCG ATC TGG CTT GTT CTA CAA TCG TAA TCA GTT AG-3'. The Indium-Tin Oxides (ITO) were obtained from Zhuhai Kaivo Optoelectronic Technology Co., Ltd (China). Phosphate Buffered Saline (PBS) was prepared by using $\mathrm{Na}_{2} \mathrm{HPO}_{4} \cdot 12 \mathrm{H}_{2} \mathrm{O}$ $(0.1 \mathrm{~mol} / \mathrm{L})$ and $\mathrm{KH}_{2} \mathrm{PO}_{4}(0.1 \mathrm{~mol} / \mathrm{L})$ solution. All other chemicals were of analytical reagent grade and deionized water was utilized in all experiments.

\section{APPARATUS.}

Photoluminescence (PL) emission spectra were analyzed by Horiba Fluoro Max-4 spectrophotometer. X-ray photoelectron spectroscopy (XPS) tests were performed on a 2000 XPS system with a monochromatic Al K $\alpha$ source and a charge 
neutralizer. Energy dispersive spectrometer (EDS) and scanning electron microscope (SEM) images were obtained using a field emission SEM (Zeiss, Germany). X-ray diffraction (XRD) patterns were obtained from a Bruker D8 Advance X-ray diffractometer. Transmission electron microscopy (TEM) and high-resolution transmission electron microscopy (HRTEM) images were obtained through a JEOL-2100F TEM (Japan). UV-vis absorbance spectra and diffuse reflectance ultraviolet-visible light spectra (DRS) were measured on a UV-vis spectrophotometer (Cary 500 Scan Spectrophotometers, Varian, and USA). Electrochemical impedance spectroscopy (EIS) performed on an electrochemical workstation (Princeton PARSTAT 3000A-DX, USA) with a three-electrode system, using $\left[\mathrm{Fe}(\mathrm{CN})_{6}\right]^{3-/ 4-}$ as redox probe. A traditional three electrode system composed of modified ITO electrode as the working electrode, an $\mathrm{Hg} / \mathrm{Hg}_{2} \mathrm{Cl}_{2}$ electrode (SCE) as reference electrode and a Pt wire electrode as counter electrode.

\section{The Synthesis of Ce-UiO-66.}

In a typical synthesis, Cerium-doped UiO-66 has been prepared by solvent thermal method. $1 \mathrm{mmol}(0.373 \mathrm{~g})$ of $\mathrm{CeCl}_{3} \cdot 7 \mathrm{H}_{2} \mathrm{O}$ was dissolved in $10 \mathrm{~mL}$ of DMF to form solution A. The rest ofthe solventthermal and purification process were same as the method of the UiO-66. 1 mmol $(0.233 \mathrm{~g}) \mathrm{ZrCl}_{4}, 1 \mathrm{mmol}(0.166 \mathrm{~g})$ 1,4-benzendicarboxylic acid $\left(\mathrm{H}_{2} \mathrm{BDC}\right)$ and $1.66 \mathrm{~mL}$ acetic acid were dissolved in 50 $\mathrm{mL}$ of DMF to form solution $\mathrm{B}$. And then, the solution $\mathrm{A}$ was added to $\mathrm{B}$, the mixture solution was string for $1 \mathrm{~h}$. The clear and colorless solution was then transferred into a $100 \mathrm{~mL}$ Teflon-lined stainless steel autoclave and heated to $120^{\circ} \mathrm{C}$ for $48 \mathrm{~h}$. After 
cooled to room temperature, the products were collected by centrifugation and wash three times with DMF and anhydrous ethanol, respectively, and then the solid was dried at $110^{\circ} \mathrm{C}$ under vacuum for $12 \mathrm{~h}$ to remove the excess of an unreacted organic linker and DMF. 


\section{FIGURE CAPTIONS:}

Fig. S1 HRTEM images of RCUMB.

Fig. S2 Elemental mapping images of RCUMB.

Fig. S3 XPS spectra of RCUMB. High-resolution XPS spectra of (A) Ce 3d, (B) Zr 3d, (C) O 1s, (D) C 1s, (E) Ru 3d, (F) Mn 2p, (G) Bi 4f and (H) S 2p.

Fig. S4 Specificity detection of OFL in water samples:(a) $5 \mathrm{nmol} / \mathrm{L}$ OFL, (b) 5 $\mathrm{nmol} / \mathrm{L} \mathrm{OFL}+500 \mathrm{nmol} / \mathrm{L}$ tetracycline, (c) $5 \mathrm{nmol} / \mathrm{L} \mathrm{OFL}+500 \mathrm{nmol} / \mathrm{L}$ tobramycin, (d) $5 \mathrm{nmol} / \mathrm{L} \mathrm{OFL}+500 \mathrm{nmol} / \mathrm{L}$ amoxicillin, (e) $50 \mathrm{nmol} / \mathrm{L}$ tetracycline, (f) 50 $\mathrm{nmol} / \mathrm{L}$ tobramycin, and (g) $50 \mathrm{nmol} / \mathrm{L}$ amoxicillin.

Table S1 Simulation parameters of the equivalent circuit components.

Table S2 Comparison of Different Detection Methods for OFL.

Table S3 The results of OFL detection in real samples by the PEC sensor. 


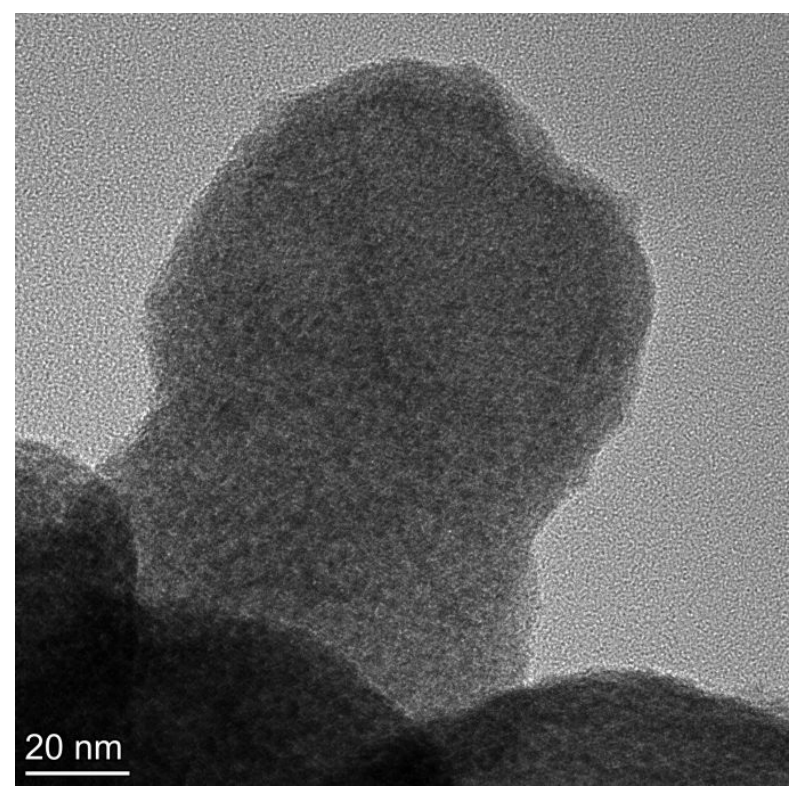

Fig. S1. TEM images of RCUMB.
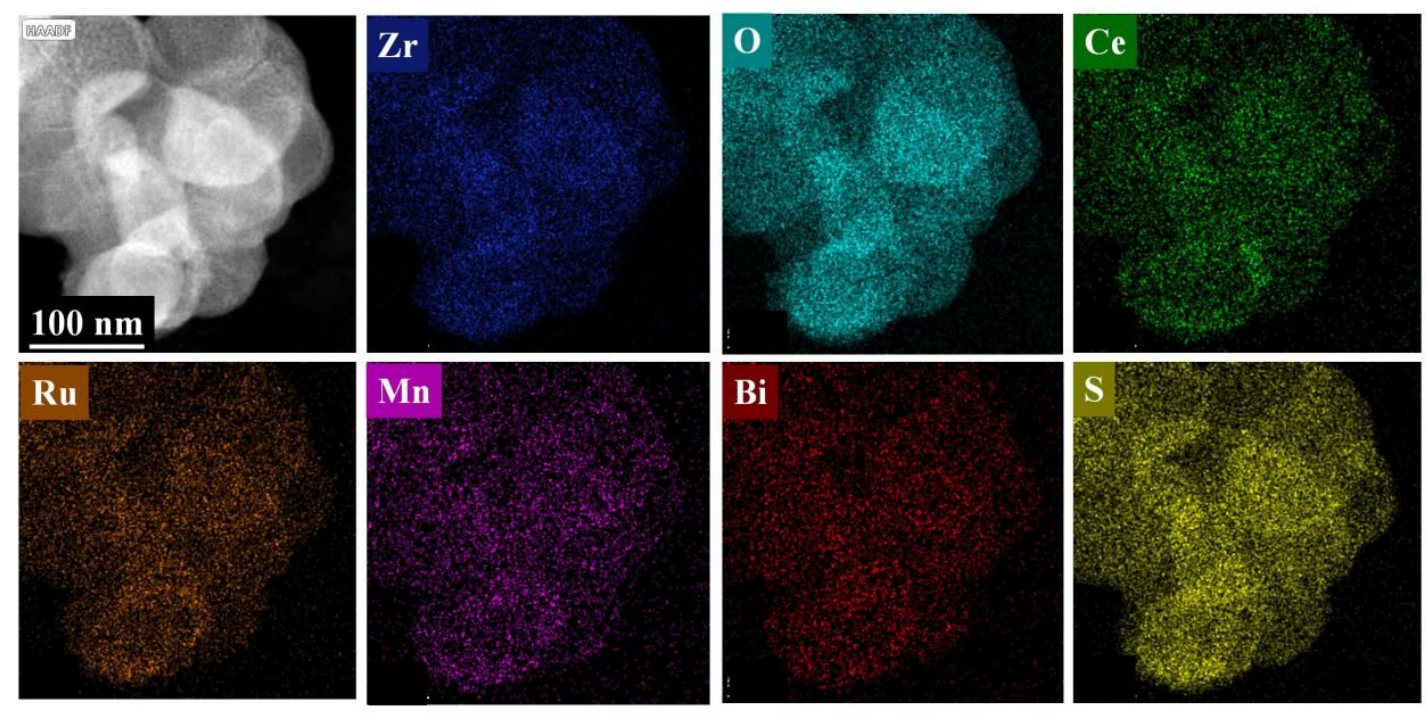

Fig. S2. Elemental mapping images of RCUMB. 

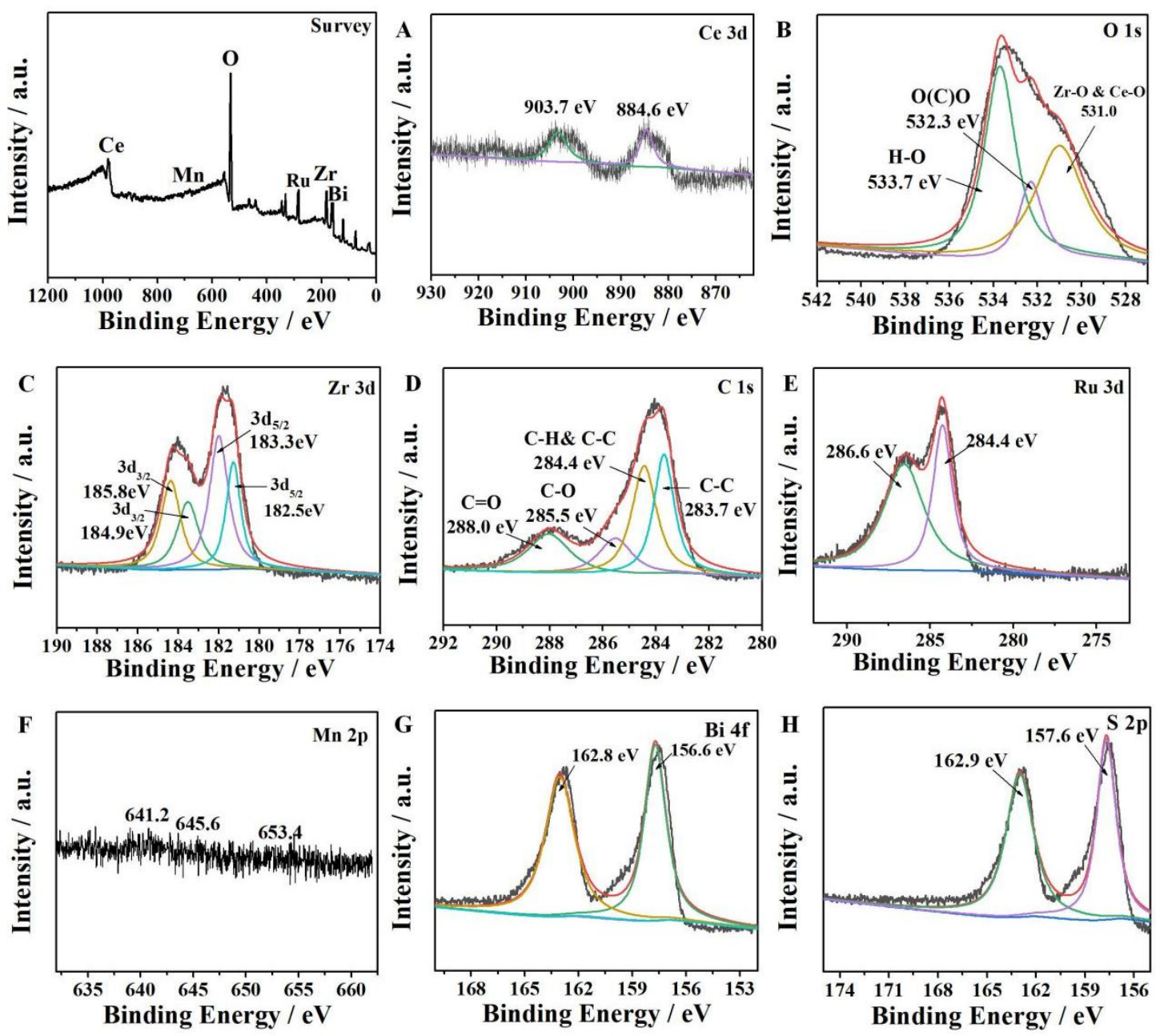

Fig. S3. XPS spectra of (A) RCUMB. High-resolution XPS spectra of (A) Ce 3d, (B)

$$
\text { Zr 3d, (C) O 1s, (D) C 1s, (E) Ru 3d, (F) Mn 2p, (G) Bi 4f, (H) S 2p. }
$$

As displayed in Fig. S3A, the binding energies of Ce $3 \mathrm{~d}$ at $884.6 \mathrm{eV}$ and 903.7 eV correspond to $\mathrm{Ce} 3 \mathrm{~d}_{5 / 2}$ and $\mathrm{Ce} 3 \mathrm{~d}_{3 / 2}$, respectively [1]. It was declared that Ce could be also a metallic center binding with $\mathrm{H}_{2} \mathrm{BDC}$. The $\mathrm{O}$ 1s peak appears at $531.0 \mathrm{eV}$, $532.3 \mathrm{eV}$ and $533.7 \mathrm{eV}$ (Fig. S3B), which could be assigned to the $\mathrm{H}-\mathrm{O}, \mathrm{O}=\mathrm{C}=\mathrm{O}$ and metal-oxygen bond, respectively [2]. Detailedly, the binding energy at $532.3 \mathrm{eV}$ can be assigned to the $\mathrm{C}=\mathrm{O}$ groups and the peaks at $533.7 \mathrm{eV}$ can be attributed to $\mathrm{H}_{2} \mathrm{O}$. The peaks at $531.0 \mathrm{eV}$ correspond to the $\mathrm{Ce}-\mathrm{O}$ and $\mathrm{Zr}-\mathrm{O}$. The $\mathrm{Zr} 3 \mathrm{~d}$ spectrum 
presented in Fig. S3C showed that the spectrum observed at 184.9 and $185.8 \mathrm{eV}$ were ascribed to the $\mathrm{Zr} 3 \mathrm{~d}_{3 / 2}$ while the spectrum at 183.3 and $182.5 \mathrm{eV}$ were assigned to the Zr 3d $d_{5 / 2}$ [3]. The C 1s spectrum (Fig. S4D) showed four peaks located at 283.7, 284.4, 285.5 and $288.0 \mathrm{eV}$, corresponding to $\mathrm{C}-\mathrm{C}, \mathrm{C}-\mathrm{C} \& \mathrm{C}-\mathrm{H}, \mathrm{C}-\mathrm{O}$ and $\mathrm{C}=\mathrm{O}$, respectively [2]. The spectrum of Ru $3 \mathrm{~d}$ in Fig. S3E displayed that the peak located at $286.6 \mathrm{eV}$ was ascribed to $\mathrm{Ru} 3 \mathrm{~d}_{3 / 2}$ [4]. Since the carrier was carbon material, the orbit of $\mathrm{Ru} 3 \mathrm{~d}_{5 / 2}$ coincided with the orbit of $\mathrm{C} 1 \mathrm{~s}$ at around $284.4 \mathrm{eV}$. The Mn had a very weak peak intensity, therefore the surface atom content of Mn is very low. Fig. S3F showed spin-orbit split levels Mn 2 $\mathrm{p}_{3 / 2}$ (at around $641.2 \mathrm{eV}$ and $645.6 \mathrm{eV}$ ) and Mn 2p $\mathrm{p}_{1 / 2}$ (at around $653.4 \mathrm{eV}$ ) [5]. In the $\mathrm{Bi} 4 \mathrm{f}$ spectrum (Fig. S3G), there are two strong peaks at 156.6 and $162.8 \mathrm{eV}$, both are attributed to $\mathrm{Bi} 4 \mathrm{f}_{7 / 2}$ and $\mathrm{Bi}_{4 / 2}$ of $\mathrm{Bi}^{3+}[6]$. The peak of S 2p (Fig. S3H) could be divided into two peaks. It could be observed that the centers at $157.6 \mathrm{eV}$ and $162.9 \mathrm{eV}$ were assigned to $\mathrm{S} 2 \mathrm{p}_{3 / 2}$ and $\mathrm{S} 2 \mathrm{p}_{1 / 2}$, respectively [7]. The orbit of $\mathrm{S} 2 \mathrm{p}_{1 / 2}$ coincided with the orbit of $\mathrm{Bi} 4 \mathrm{f}_{5 / 2}$ at around $162.9 \mathrm{eV}$. 


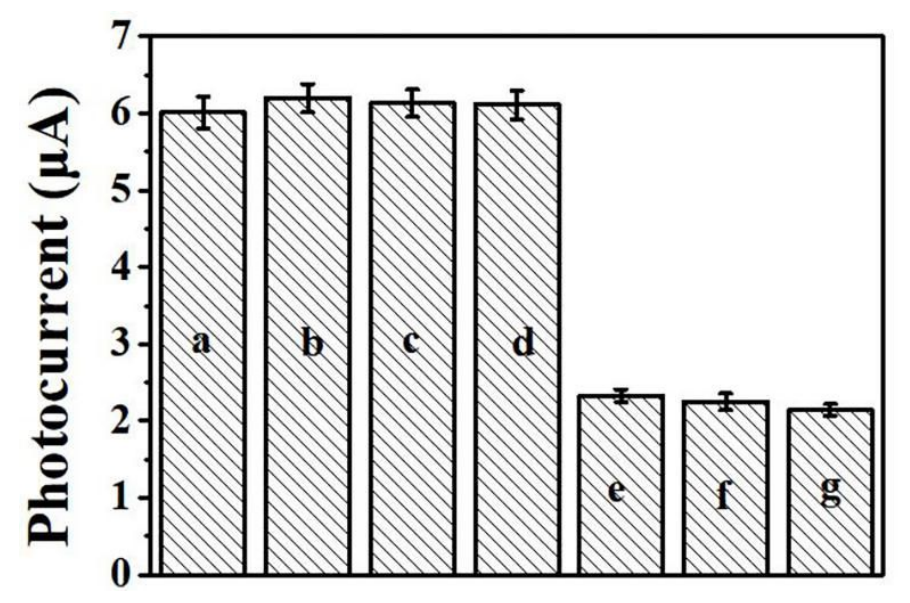

Fig. S4. Specificity detection of OFL in water samples: (a) $5 \mathrm{nmol} / \mathrm{L}$ OFL, (b) 5 $\mathrm{nmol} / \mathrm{L} \mathrm{OFL}+500 \mathrm{nmol} / \mathrm{L}$ tetracycline, (c) $5 \mathrm{nmol} / \mathrm{L} \mathrm{OFL}+500 \mathrm{nmol} / \mathrm{L}$ tobramycin,

(d) $5 \mathrm{nmol} / \mathrm{L} \mathrm{OFL}+500 \mathrm{nmol} / \mathrm{L}$ amoxicillin, (e) $50 \mathrm{nmol} / \mathrm{L}$ tetracycline, (f) 50 $\mathrm{nmol} / \mathrm{L}$ tobramycin, and (g) $50 \mathrm{nmol} / \mathrm{L}$ amoxicillin.

As shown in Fig. S4, the photocurrent showed no obvious change after 50 $\mathrm{nmol} / \mathrm{L}$ tetracycline, tobramycin and amoxicillin were incubated on the blank electrode respectively in the presence or absence of OFL. The results indicating an acceptable selectivity of PEC sensor in practical application. 


\section{Table S1.}

Simulation parameters of the equivalent circuit components.

\begin{tabular}{lcccc}
\hline \multicolumn{1}{c}{ Electrode } & $R_{\mathrm{S}}(\Omega)$ & $R_{\mathrm{et}}(\Omega)$ & $C_{\mathrm{dl}}(\mathrm{F})$ & $Z_{\mathrm{W}}$ \\
\hline ITO & 56.11 & 15.24 & $0.500 \times 10^{-6}$ & 0.003316 \\
$\mathrm{RCU} / \mathrm{ITO}$ & 62.40 & 22.25 & $1.024 \times 10^{-6}$ & 0.002763 \\
$\mathrm{Mn}: \mathrm{Bi}_{2} \mathrm{~S}_{3} / \mathrm{RCU} / \mathrm{ITO}$ & 66.10 & 35.46 & $1.184 \times 10^{-6}$ & 0.002842 \\
aptamer/RCUMB/ITO & 65.78 & 47.46 & $0.413 \times 10^{-6}$ & 0.000887 \\
MCH/aptamer/RCUMB/ITO & 72.20 & 99.80 & $0.289 \times 10^{-6}$ & 0.001048 \\
OFL/MCH/aptamer/RCUMB/ITO & 69.44 & 71.80 & $1.082 \times 10^{-6}$ & 0.001952 \\
\hline
\end{tabular}

In the EIS experiments, our instrument parameters of frequency range and amplitude were set as $100 \mathrm{mHz} \sim 100 \mathrm{kHz}$ and $5 \mathrm{mV}$ respectively. The bias voltage remained the default $0 \mathrm{~V}$. The buffer solution used in the tests was a kind of mixed solution containing $2.5 \mathrm{mmol} / \mathrm{L} \mathrm{K}_{3}\left[\mathrm{Fe}(\mathrm{CN})_{6}\right], 2.5 \mathrm{mmol} / \mathrm{L} \mathrm{K}_{4}\left[\mathrm{Fe}(\mathrm{CN})_{6}\right]$ and $0.1 \mathrm{~mol} / \mathrm{L}$ $\mathrm{KCl}$.

The electrons were generated by the redox reactions of the redox probe $\left(\left[\mathrm{Fe}(\mathrm{CN})_{6}\right]^{3-/ 4-}\right)$ at the interface between the electrolyte and the electrodes during the EIS measurements ${ }^{5}$. The specific process is as follows:

oxidation reaction: $\mathrm{Fe}^{3+}-\mathrm{e}^{-} \rightarrow \mathrm{Fe}^{4+} \quad$ reduction reaction: $\mathrm{Fe}^{4+}+\mathrm{e}^{-} \rightarrow \mathrm{Fe}^{3+}$. 


\section{Table S2.}

Comparison of Different Detection Methods for OFL.

\begin{tabular}{|c|c|c|c|c|c|}
\hline $\begin{array}{l}\text { Detection } \\
\text { techniques }\end{array}$ & Method & $\begin{array}{l}\text { Linear } \\
\text { range } \\
(\mathrm{nmol} / \mathrm{L})\end{array}$ & $\begin{array}{c}\text { Detection } \\
\text { limit } \\
(\mathrm{nmol} / \mathrm{L})\end{array}$ & Application & Reference \\
\hline UHPLC-MS/MS & $\begin{array}{l}\text { Multi-class } \\
\text { analysis and } \\
\text { complex } \\
\text { matrices }\end{array}$ & $\begin{array}{c}\text { Not } \\
\text { mentioned }\end{array}$ & 77 & $\begin{array}{l}\text { sludge and } \\
\text { wastewater }\end{array}$ & [8] \\
\hline Chemiluminescence & $\begin{array}{c}\text { Luminol- } \mathrm{H}_{2} \mathrm{O}_{2} \\
\text {-OFL system } \\
\text { by Ag NPs }\end{array}$ & $2.8-2800$ & 0.83 & Cow milk & [9] \\
\hline $\begin{array}{c}\text { Electrochemical } \\
\text { aptasensor }\end{array}$ & Au NPs & $50-20000$ & 1 & $\begin{array}{l}\text { Tap water } \\
\text { and sewage }\end{array}$ & {$[10]$} \\
\hline $\begin{array}{l}\text { Colorimetric } \\
\text { aptasensor }\end{array}$ & $\begin{array}{c}\text { NaCl-induced } \\
\text { Au NPs } \\
\text { system }\end{array}$ & $20-400$ & 3.4 & $\begin{array}{c}\text { Application } \\
\text { potential }\end{array}$ & [11] \\
\hline $\begin{array}{l}\text { Fluorescent } \\
\text { aptasensor }\end{array}$ & $\begin{array}{l}\text { magnetic } \\
\text { separation }\end{array}$ & $0.05-50$ & 0.0321 & $\begin{array}{c}\text { Chicken and } \\
\text { pork }\end{array}$ & {$[12]$} \\
\hline PEC aptasensor & $\begin{array}{c}{\left[\mathrm{Ru}(\mathrm{bpy})_{3}\right]^{2+} @} \\
\mathrm{Ce}-\mathrm{UiO}-66 / \mathrm{M} \\
\mathrm{n}: \mathrm{Bi}_{2} \mathrm{~S}_{3}\end{array}$ & $0.01-100$ & 0.006 & $\begin{array}{c}\text { Tap and lake } \\
\text { water }\end{array}$ & This work \\
\hline
\end{tabular}




\section{Table S3.}

The results of OFL detection in real samples by the PEC sensor.

\begin{tabular}{|c|c|c|c|c|}
\hline Water samples & $\begin{array}{l}\text { Addition content } \\
\qquad(\mathrm{nmol} / \mathrm{L})\end{array}$ & $\begin{array}{l}\text { Detection content } \\
(\mathrm{nmol} / \mathrm{L})\end{array}$ & $\begin{array}{l}\mathrm{RSD} \\
(\%)\end{array}$ & $\begin{array}{c}\text { Recovery } \\
(\%)\end{array}$ \\
\hline \multirow{3}{*}{ Tap water } & 1.00 & $\begin{array}{ll}0.97 、 0.96 、 0.94 、 \\
0.99 、 1.02\end{array}$ & 3.1 & 97.6 \\
\hline & 5.00 & $\begin{array}{l}4.89 、 4.97 、 4.90 、 \\
5.05 、 5.11\end{array}$ & 1.9 & 99.7 \\
\hline & 10.00 & $\begin{array}{l}9.92 、 9.87 、 9.73 、 \\
10.02 、 10.07\end{array}$ & 1.3 & 99.2 \\
\hline \multirow{3}{*}{ Lake water } & 1.00 & $\begin{array}{l}1.03 、 1.08 、 1.05 、 \\
1.07 、 0.98\end{array}$ & 3.8 & 104.2 \\
\hline & 5.00 & $\begin{array}{l}5.17 、 5.22 、 5.19 \\
5.30 、 5.38\end{array}$ & 1.7 & 105.0 \\
\hline & 10.00 & $\begin{array}{l}10.12 、 10.25 、 10.18 \text { 、 } \\
10.31 、 9.97\end{array}$ & 1.3 & 101.7 \\
\hline
\end{tabular}




\section{REFERENCES}

[1] Yang, J.; Li, K.; Li, C.; Gu, J. Intrinsic apyrase-like activity of Cerium-based metal-organic frameworks: Dephosphorylation of adenosine tri- and diphosphate. Angew. Chem. Int. Ed. 2020, 132(51), 23152-23156.

[2] Yang, Z.; Xu, X.; Liang, X.; Lei, C.; Gao, L.; Hao, R.; Lu, D.; Lei, Z. Fabrication of Ce doped UiO-66/graphene nanocomposites with enhanced visible light driven photoactivity for reduction of nitroaromatic compounds. Appl. Surf. Sci. 2017, 420, $276-285$

[3] Xu, J.; He, S.; Zhang, H. L.; Huang, J. C.; Lin, H. X.; Wang, X. X.; Long, J. L. Layered metal-organic framework/graphene nanoarchitectures for organic photosynthesis under visible light. J. Mater. Chem. A 2015, 48, 24261-24271.

[4] Al-Hinaai, M. M.; Kyaw, H. H.; Al-Harthi, S. H.; Khudaish, E. A. An innovative ECL sensor based on AuNPs linker for $\mathrm{Ru}(\mathrm{bpy}) 3_{3}{ }^{2+}$ molecules doped onto an alkaline pretreatedpoly(4-aminodiphenylamine) film. Sensor. Actuat. B-Chem. 2018, 257, $460-468$

[5] Majid, A.; Ahmad, N.; Rizwan, M.; Khan, S. U.; Ali, F. A. A.; Zhu, J. Effects of Mn ion implantation on XPS spectroscopy of GaN thin films. J. Electron. Mater. 2018, 47, 1555-1559.

[6] Thomson, J. W.; Cademartiri, L.; MacDonald, M.; Petrov, S.; Calestani, G.; Zhang, P.; Ozin, G. A. Ultrathin $\mathrm{Bi}_{2} \mathrm{~S}_{3}$ nanowires: Surface and core structure at the Cluster-Nanocrystal transition. J. Am. Chem. Soc. 2010, 132, 9058-9068.

[7] Qu, D.; Zheng, M.; Du, P.; Zhou, Y.; Zhang, L.; Li, D.; Tan, H.; Zhao, Z.; Xie, Z.; 
Sun, Z. Highly luminescent S, N co-doped graphene quantum dots with broad visible absorption bands for visible light photocatalysts. Nanoscale 2013, 5, 12272-12277.

[8] Cavaillé1, L.; Kim, C.; Bounouba, M.; Zind, H.; Claparols, C.; Ribou, D.; Pinelli, E.; Albasi, C.; Bessiere, Y. Development and validation of QuEChERS-based extraction for quantification of nine micropollutants in wastewater treatment plant. Anal. Bioanal. Chem. 2021, DOI: 10.1007/s00216-021-03489-z.

[9] Liu, W.; Guo, Y. M.; Li, H. F.; Zhao, M.; Lai, Z. S.; Li, B. X. A paper-based chemiluminescence device for the determination of ofloxacin. Spectrochim. Acta A 2015, 137, 1298-1303.

[10] Pilehvar, S.; Reinemann, C.; Bottari, F.; Vanderleyden, E.; Van Vlierberghe, S.; Blust, R.; Strehlitz, B.; De Wael, K. A joint action of aptamers and gold nanoparticles chemically trapped on a glassy carbon support for the electrochemical sensing of ofloxacin. Sensor. Actuat. B-Chem. 2017, 240, 1024-1035.

[11] Zhou, X. T.; Wang, L. M.; Shen, G. Q.; Zhang, D. W.; Xie, J. L.; Mamut, A.; Huang, W. W.; Zhou, S. S. Colorimetric determination of ofloxacin using unmodified aptamers and the aggregation of gold nanoparticles. Microchim. Acta 2018, 185, 355. [12] Huang, Y.; Wang, C.; Huo, Q.; Song, Y.; Du, G.; Wang, L.; Yang, X.; Chen, X. A time-resolved luminescence aptasensor of ofloxacin based on rolling circle amplification and magnetic separation. Anal. Bioanal. Chem. 2020, 412, 4555-4563. 